Metallomics

\title{
Effects of non-toxic zinc exposure on human epidermal keratinocytes
}

Eszter Emri ${ }^{1}$, Edit Miko ${ }^{1}$, Péter Bai ${ }^{2,5,6}$, Gábor Boros ${ }^{1}$, Georgina Nagy ${ }^{1,3}$, Dávid Rózsa ${ }^{1}$, Tamás Juhász ${ }^{4}$, Csaba Hegedüs ${ }^{1}$, Irén Horkay ${ }^{1}$, Éva Remenyik ${ }^{1 *}$, Gabriella Emri ${ }^{1}$

Departments of ${ }^{1}$ Dermatology, ${ }^{2}$ Medical Chemistry, ${ }^{3}$ Dermatological Allergology, and ${ }^{4}$ Anatomy, Histology, and Embryology, Faculty of Medicine, University of Debrecen, 4032, Debrecen, Hungary

${ }^{5}$ Research Center for Molecular Medicine, University of Debrecen, Debrecen, 4032, Hungary

${ }^{6}$ MTA-DE Lendület Laboratory of Cellular Metabolism Research Group, of the Hungarian Academy of Sciences 4032, Debrecen, Hungary

Keywords: zinc, heme oxygenase-1, ultraviolet radiation, superoxide, apoptosis

* All correspondence should be sent to:

Éva Remenyik, M.D., D.Sc.

Department of Dermatology

Faculty of Medicine, University of Debrecen

Nagyerdei krt. 98. H-4032, Debrecen, Hungary

Ph.: +36-52-411-600; F.: +36-52-414-632; E-mail: remenyik@med.unideb.hu 


\title{
Metallomics
}

\begin{abstract}
Zinc is an essential microelement; its importance to skin is shown by severe skin symptoms in hereditary or acquired zinc deficiency, by the improvement of several skin conditions using systemic or topical zinc preparations and by the induced intracellular zinc release upon UVB exposure, which is the main harmful environmental factor to skin. Understanding the molecular background of the role of zinc in skin may help to gain insight into the pathology of skin disorders and to provide evidence for the therapeutic usefulness of zinc supplementation. Herein, we studied the effect of zinc chloride $\left(\mathrm{ZnCl}_{2}\right)$ exposure on the function of HaCaT keratinocytes, and we found that a non-toxic elevation in the concentration of extracellular zinc $(100 \mu \mathrm{M})$ facilitated cell proliferation and induced significant alterations in the mRNA expression of NOTCH1, IL8, and cyclooxygenase-2. In addition, we detected increased heme oxygenase-1 (HMOX1) expression and non-toxic generation of superoxide in the first $4 \mathrm{~h}$. Regarding the effect on UVB-induced toxicity, although the level of cyclobutane pyrimidine dimers in keratinocytes pre-treated with zinc for $24 \mathrm{~h}$ was reduced $3 \mathrm{~h}$ after UVB irradiation, we found significantly enhanced superoxide generation $10 \mathrm{~h}$ after UVB exposure in the zinc pre-exposed cells. The overall survival was unaffected; however, there was a decrease in the percentage of early apoptotic cells and an increase in the percentage of late apoptotic plus necrotic cells.

Our results suggest that exposure of human keratinocytes to non-toxic concentrations of $\mathrm{ZnCl}_{2}$ impacts gene expression, cell proliferation and the response to environmental stress in skin. It would be important to further examine the role of zinc in skin and to further clarify if this issue can affect our thinking about the pathogenesis of skin diseases.
\end{abstract}




\section{Introduction}

Zinc is an essential microelement, and its importance in skin is shown by the severe skin symptoms of hereditary or acquired zinc deficiency, including erythaematous rashes, scaly plaques, and ulcers at orifices and acra ${ }^{1,2}$, and by the ability of systemic or topical zinc preparations to improve hair loss, acne and several inflammatory skin conditions ${ }^{3}$.

Zinc content of the body is associated with skin by approximately $9 \%$, primarily with the epidermis (50-70 $\mathrm{gg} \mathrm{g}^{-1}$ dry weight) ${ }^{4,5}$, and $50 \%$ of the available zinc is localised to the cytoplasm, while $30-40 \%$ is localised in the nucleus, and the remainder is associated with the plasma membrane ${ }^{6}$. The cellular level and distribution of zinc is tightly controlled by zinc importers and transporters ${ }^{7}$. The metallothionein (MT)/thionein couple sequester or release zinc depending on the local redox state, thereby influencing the function of numerous proteins, transcription factors and enzymes ${ }^{8}$. An imbalance in the MT protein level can be detected in different skin cancers, in squamous cell carcinoma and in malignant melanoma 9 , ${ }^{10}$. Indeed, the prevalence of genes encoding zinc proteins is estimated to be over $3 \%$ of the 32,000 identified genes ${ }^{3}$. According to Schwartz et al., over 300 zinc-dependent enzymes have been identified and characterised ${ }^{11}$. A close relation between redox homeostasis and the regulation of different protein functions by zinc can provide an important, fine-tuned control mechanism in the cell, but this process has been evidenced biochemically and has not been well studied in biological systems. On the other hand, zinc exposure of skin keratinocytes via cosmetic products, sunscreens and dermatological topical treatment occurs daily ${ }^{4,12}$. The toxic effects of zinc pirithion and zinc oxide on the epidermis have been demonstrated ${ }^{13,14}$; however, it is not known whether nontoxic zinc exposure can impact the physiological functions of keratinocytes or influence the effects of other environmental factors.

Ultraviolet light B (UVB) irradiation of human skin is known to induce pathophysiological processes such as oxidative stress and inflammation and is regarded as the main pathogenic factor of skin cancer development. UVB causes skin cell damage directly by inducing the production of cyclobutane pyrimidine dimers (CPDs) and indirectly by triggering the production of reactive species and interfering with cellular redox homeostasis. Importantly, rapid intracellular elevation of zinc levels occurs in keratinocytes after UVB irradiation ${ }^{15,16}$, and the level of MT is higher in the epidermis after acute UV exposure, while the skin of MT knockout mice is more susceptible to UVB ${ }^{17}$. Previously, it was found that solar (i.e., mixed) UV irradiation of keratinocytes exposed to zinc chloride $\left(\mathrm{ZnCl}_{2}\right)$ enhances cell survival and is able to reduce the immediate DNA damage ${ }^{18,19}$ and DNA fragmentation after exposure ${ }^{20}$. In 


\section{Metallomics}

this study, we aimed to obtain further experimental evidence on the effect of $\mathrm{Zn}$ (II) exposure on human keratinocyte function in conventional culture and under stressed conditions using UVB irradiation, the main environmental harmful factor to skin. 
Metallomics

\section{Materials and methods}

\subsection{Cell culture, UVB-irradiation apparatus, and $\mathrm{ZnCl}_{2}$ treatment}

HaCaT human keratinocytes were obtained from ATCC and maintained in high-glucose DMEM (PAA, Traun, Austria) supplemented with 10\% foetal bovine serum ((FBS) Lonza, Verviers, Belgium), 2 mM L-glutamine (PAA, Traun, Austria), $100 \mathrm{U} / \mathrm{mL}$ penicillin G, 0.1 $\mathrm{mg} / \mathrm{mL}$ streptomycin sulphate, and $0.25 \mu \mathrm{g} / \mathrm{mL}$ amphotericin B (Sigma-Aldrich, St. Louis, MO, USA) in an atmosphere of $5 \% \mathrm{CO}_{2}$ at $37^{\circ} \mathrm{C}$. In the UV irradiation experiments, the culture medium was replaced with sufficient phosphate-buffered saline (PBS) (DPBS, Lonza, Verviers, Belgium) to avoid dehydration. The cells were then exposed to UVB $\left(20 \mathrm{~mJ} / \mathrm{cm}^{2}\right)$ using a TL20W/12 RS broadband, filtered UVB lamp (Philips, Germany), which had an emission spectrum of 280-370 nm, with a peak at $312 \mathrm{~nm}$. The UV intensity was controlled with a UV light meter (UVP Inc., San Gabriel, USA). The original medium was replaced after treatment. A 0.1-M stock solution of $\mathrm{ZnCl}_{2}$ (Sigma-Aldrich, St. Louis, MO, USA) was prepared in deionised water and sterilised with a $0.2-\mu \mathrm{m}$ sterile filter. A working concentration of $100 \mu \mathrm{M}$ (unless stated otherwise) was selected according to previous reports 20 .

\subsection{Apoptosis assay}

Cells were pre-treated with $\mathrm{ZnCl}_{2}$ for $24 \mathrm{~h}$ and then exposed to UVB. Afterward, apoptosis was measured $24 \mathrm{~h}$ after UVB exposure. Harvested cells $\left(5 \times 10^{5}\right)$ were washed in ice-cold PBS and stained with Annexin V and propidium iodide (PI) using the Vybrant apoptosis assay Kit (Invitrogen, Eugene, Oregon, USA) according to the manufacturer's protocol. The stained cells were analysed by flow cytometry $\left(\right.$ CyFlow ${ }^{\circledR}$ Space, Partec, Canterbury, United Kingdom) using UV/488 nm dual-excitation, measuring the fluorescence emission at 530 and $575 \mathrm{~nm}$. Annexin $\mathrm{V}^{-} \mathrm{PI}^{-}$cells were identified as viable cells, Annexin $\mathrm{V}^{+} \mathrm{PI}^{-}$cells were identified as early apoptotic cells, and the sum of the Annexin $\mathrm{V}^{+} \mathrm{PI}^{+}$and Annexin $\mathrm{V}^{-} \mathrm{PI}^{+}$cells was identified as late apoptotic plus necrotic cells.

\subsection{Cell proliferation}




\section{Metallomics}

Cells were treated with 50 or $100 \mu \mathrm{M} \mathrm{ZnCl}$ for $72 \mathrm{~h}$, and cell proliferation was measured using the EZ4U assay (Biomedica, Vienna, Austria) according to the manufacturer's instructions. The optical density (OD) was determined at $450 \mathrm{~nm}$ using an Anthos 2020 microplate reader (Biochrom Ltd., Cambridge, UK).

\subsection{Cyclobutane pyrimidine dimer (CPD)-ELISA}

Cells were treated with $\mathrm{ZnCl}_{2}$ for $24 \mathrm{~h}$ and/or UVB irradiated, and genomic DNA was purified 0, 1, 3, 6, and $24 \mathrm{~h}$ after UVB exposure using a QIAamp Blood Kit (Qiagen, Hilden, Germany). Ninety-six-well plates were coated with $0.003 \%$ protamine sulphate (SigmaAldrich, St. Louis, MO, USA) for 2 days at $37^{\circ} \mathrm{C}$. To measure CPD lesions, genomic DNA was diluted to $0.2 \mu \mathrm{g} / \mathrm{mL}$ in PBS, denatured at $100^{\circ} \mathrm{C}$ for $10 \mathrm{~min}$, and then chilled on ice for $15 \mathrm{~min}$. The denatured DNA solution was transferred to plates pre-coated with protamine sulphate and dried overnight at $37^{\circ} \mathrm{C}$. For blocking, the plates were washed four times with PBS-T $\left(0.05 \%\right.$ Tween-20 in PBS) and then incubated in $20 \% \mathrm{FBS}$ for $30 \mathrm{~min}$ at $37^{\circ} \mathrm{C}$. The wells were then washed four times with PBS-T and incubated with the primary CPD antibody (\#TDM-2, Cosmo Bio Co. Ltd., Tokyo, Japan) at a 1:1000 dilution in PBS for $30 \mathrm{~min}$ at $37^{\circ} \mathrm{C}$. The wells were then washed and incubated with the HRP-conjugated anti-mouse IgG secondary antibody (BioRad, Hercules, CA, USA) diluted 1:3000 in PBS for 30 min at $37^{\circ} \mathrm{C}$. After incubation, the cells were washed four times with PBS-T and then once with citratephosphate buffer ( $\mathrm{pH}$ 5.0). Following buffer removal, the wells were incubated with a substrate solution (o-phenylene diamine (Sigma-Aldrich, St Louis, MO, USA), $\mathrm{H}_{2} \mathrm{O}_{2}$, and citrate-phosphate buffer ( $\mathrm{pH} \mathrm{5.0)}$ ) for $10 \mathrm{~min}$ at $37^{\circ} \mathrm{C}$, at which time the enzyme reaction was stopped with $2 \mathrm{M} \mathrm{H}_{2} \mathrm{SO}_{4}$. The absorbance was measured using an Anthos 2020 microplate reader (Biochrom Ltd., Cambridge, UK) at $492 \mathrm{~nm}$, and the OD values of the untreated cells were subtracted from those of the treated cells.

\subsection{TaqMan Low-Density Array (TLDA)}

Cells were treated with $\mathrm{ZnCl}_{2}$ for 4 or $24 \mathrm{~h}$, and relative gene expression was measured. In a parallel experiment, cells were pre-treated with $\mathrm{ZnCl}_{2}$ for $24 \mathrm{~h}$ and then UVB irradiated. Six hours after exposure, total RNA was isolated using Trizol Reagent (MRC Inc., Cincinnati, Ohio, USA), and total RNA was quantified using a Nanodrop 2000 (Thermo Fisher Scientific, Wilmington, USA). cDNA was then synthesised using the High-Capacity cDNA Reverse 
Metallomics

Transcription kit (Applied Biosystems, Foster City, CA, USA) according to the manufacturer's instructions. We designed Custom TaqMan Array Microfluidic Cards (384well) by first selecting 91 genes based on their roles connected to zinc and the UVB response. The selected genes were involved in cell cycle progression, inflammation, apoptosis, DNA repair, and antioxidant defence (Supplementary 1). Genes connected with zinc homeostasis and some with an identified MRE in the promoter region were also added. The TLDA was performed using an Applied Biosystems 7900HT Real-Time PCR System according to the manufacturer's protocol. cDNA (100 ng) in $100 \mu \mathrm{L}$ of 1X Taqman Gene Expression Master Mix (Applied Biosystems, Foster City, CA, USA) was loaded into each port of the TLDA plates, and each sample was examined in pairs. The PCR program used for amplification was as follows: $94^{\circ} \mathrm{C}$ for $1 \mathrm{~min} ; 40$ cycles of $94^{\circ} \mathrm{C}$ for $12 \mathrm{sec}$; and $60^{\circ} \mathrm{C}$ for $45 \mathrm{sec}$. The data were derived from three independently performed experiments and were analysed using SDS 2.1 software. ACTB, GAPDH, SDHA, and PGK1 were used for normalisation. Relative gene expression values were calculated using the $2^{\text {-ddCt }}$ method ${ }^{21,22}$.

\subsection{Measurement of superoxide $\left(\mathrm{O}_{2}{ }^{--}\right)$production}

After 4 or $24 \mathrm{~h}$ of $\mathrm{ZnCl}_{2}$ treatment or after $24 \mathrm{~h}$ of $\mathrm{ZnCl}_{2}$ treatment combined with $\mathrm{UVB}$, the production of $\mathrm{O}_{2}{ }^{--}$was measured using a dihydroethidium (HE) assay (Sigma-Aldrich, St. Louis, MO, USA) 1, 4, 10, and $24 \mathrm{~h}$ after UVB exposure. A working solution of $\mathrm{HE}$ at a $2 \mu \mathrm{M}$ final concentration was added to the cells and then incubated for $30 \mathrm{~min}$ at $37^{\circ} \mathrm{C}$. The cells were then harvested, and the fluorescence intensity was measured by flow cytometry with a FACSCalibur (BD Biosciences, San Jose, USA) to determine the fluorescence intensity at 450 $\mathrm{nM}$, with $620 \mathrm{~nm}$ as a reference. The production of $\mathrm{O}_{2}^{-{ }^{-}}$was expressed as the mean of HEfluorescence intensity ${ }^{23}$.

\subsection{Detection of hydrogen peroxide}

After 4, 10 or $24 \mathrm{~h}$ of $\mathrm{ZnCl}_{2}$ treatment, hydrogen peroxide production was determined using an Amplex red (10-acetyl-3,7-dihydroxyphenoxazine) assay. In this assay, a working solution of Amplex Red (Invitrogen, Eugene, Oregon, USA) at a $50-\mu \mathrm{M}$ final concentration and horseradish peroxidase (Sigma-Aldrich, St. Louis, MO, USA) at a $0.1 \mathrm{U} / \mathrm{ml}$ final concentration was added to the cells and then incubated for $20 \mathrm{~min}$ at room temperature. Fluorescence was subsequently read, with excitation at $530 \mathrm{~nm}$ and emission at $590 \mathrm{~nm}$, using 


\section{Metallomics}

a Fluoroskan Ascent FL plate reader (Thermo Scientific, Vantaa, Finland). The MFI values of untreated cells were subtracted from those of the treated cells.

\subsection{Western blotting}

Cells were treated with $\mathrm{ZnCl}_{2}$ for 4, 24, 48 or $72 \mathrm{~h}$ and lysed in RIPA buffer (Sigma-Aldrich, St. Louis, MO, USA). The protein concentration was then estimated using a BCA protein assay kit (Pierce Biotechnology, Rockford, USA). Proteins (20 $\mu \mathrm{g})$ were separated on 10 or $12 \%$ SDS-polyacrylamide gels and then transferred onto nitrocellulose membranes by electroblotting. The membranes were then blocked with $5 \%$ low-fat milk in TTBS $(0.1 \%$ Tween-20 in Tris-buffered saline) or in PBST (0.05\% Tween-20 in PBS) and incubated overnight with primary antibody against heme oxygenase-1 (HMOX1) (\#ab13248, Abcam Inc., Cambridge, USA) at 1:250 dilution or MTI/II (\#ab12228, Abcam Inc., Cambridge, USA) at $1: 1000$ dilution in $5 \%$ milk at $4{ }^{\circ} \mathrm{C}$. The membranes were then washed and incubated with horseradish peroxidase-conjugated secondary antibody for $1 \mathrm{~h}$ at room temperature. After washing, the signals were visualised using ECLTM Prime Western Blotting Detection Reagent (GE Healthcare, Freiburg, Germany). $\beta$-actin (Cell Signaling Technology Inc., Danvers, MA, USA) was used for normalisation.

\subsection{Statistics}

Statistical analysis was performed using GraphPad Prism Software 5.03 (GraphPAD Software Inc., San Diego, CA, USA), and p values were calculated using a 2-tailed Student's t test. Statistical significance was accepted when $\mathrm{p}<0.05$. 
Metallomics

\section{Results}

\subsection{Zn (II) increased cell proliferation}

To examine the effect of $\mathrm{Zn}$ (II) exposure on cell proliferation, $\mathrm{HaCaT}$ cells were treated with $\mathrm{Zn}$ (II) at concentrations of 50 and $100 \mu \mathrm{M}$ in growth medium containing $10 \% \mathrm{FBS}$, and the effects were measured using an EZ4U assay. We found that 72 -h treatment with $100 \mu \mathrm{M} \mathrm{Zn}$ (II) resulted in significantly increased cell proliferation (1.3-fold; $\mathrm{p}=0.045)$ (Figure 1).

3.2. Zn (II) exposure impacted the expression of genes involved in zinc homeostasis, antioxidant defence, cell viability and inflammation in HaCaT cells

Then, we identified genes that showed altered expression in response to $100 \mu \mathrm{M} \mathrm{Zn}$ (II)containing medium using TaqMan Low-Density Array analysis. We detected six significantly up-regulated genes with relative expression levels of at least 1.5-fold in $\mathrm{Zn}$ (II)-treated cells compared to the untreated controls (Table 1). The MT1F gene showed the highest overexpression at both time points following Zn (II) treatment (40.86-fold at $4 \mathrm{~h}$; 12.92-fold at $24 \mathrm{~h}$ ), and MT1X and HMOX1 were expressed more than 10-fold higher in treated cells after $4 \mathrm{~h}$ of Zn (II) exposure. The expression levels of MT1E, MT2A and SLC30A1 also showed at least a 2-fold significant difference between treated and untreated cells at both treatment times. The notch homolog 1, translocation-associated (Drosophila) (NOTCH1) gene was slightly up-regulated (1.47-fold), and we detected slight but significant suppression of IL8, prostaglandin-endoperoxide synthase 2 (PTGS2), and cytochrome P450 1B1 (CYP1B1) mRNA expression (0.63-fold, 0.68-fold, and 0.63-fold, respectively) after $4 \mathrm{~h}$ of $\mathrm{Zn}$ (II) treatment. Specific commercial antibodies against MT protein isoforms are not currently available, and the composite of MTI/II can only be investigated at the protein level. Western blot analysis demonstrated that Zn (II) treatment induced the production of MTI/II proteins with a maximum at $48 \mathrm{~h}$ (Figure $2 \mathrm{a}$ ).

3.3. Zn (II) exposure impacted the expression of $\mathrm{HMOXI}$ and induced significant $\mathrm{O}_{2}{ }^{{ }^{-}}$ production 


\section{Metallomics}

We also measured the protein expression of HMOX1 after 4 and $24 \mathrm{~h}$ of $\mathrm{Zn}$ (II) exposure (Figure 2b). Western blot analysis demonstrated that 4-h $\mathrm{Zn}$ (II) treatment induced the production of a 34-kDa HMOX1 protein.

On the other hand, the induction of the antioxidant defence protein HMOX1 upon Zn (II) exposure prompted us to examine whether Zn (II) treatment can induce reactive oxygen species. We measured the generation of $\mathrm{O}_{2}{ }^{--}$in response to $\mathrm{Zn}$ (II) exposure in cells using a flow cytometry-based $\mathrm{HE}$ assay. Our data showed significant production of $\mathrm{O}_{2}{ }^{--}$after $4 \mathrm{~h}$ of $\mathrm{Zn}$ (II) treatment compared to the control ( $\mathrm{p}=0.006$ ) (Figure 3a). To further confirm our data, we investigated $\mathrm{O}_{2}^{--}$dismutation by measuring the production of $\mathrm{H}_{2} \mathrm{O}_{2}$, and we found extracellular diffusion of $\mathrm{H}_{2} \mathrm{O}_{2}$ to the growth medium $24 \mathrm{~h}$ after $\mathrm{Zn}$ (II) treatment ( $\mathrm{p}=0.019$ ) (Figure 3b).

\subsection{Zn (II) pre-exposure decreased the amount of CPDs but enhanced UVB-induced $\mathrm{O}_{2}{ }^{\cdot-}$ generation}

To shed light on the mechanism of the zinc-mediated component of the UVB response, we characterised UVB-induced $\mathrm{O}_{2}{ }^{--}$generation and CPD formation after 24-h Zn (II) pretreatment. We examined the level of $\mathrm{O}_{2}{ }^{--}$in $\mathrm{Zn}$ (II) pre-treated, UVB-irradiated cells and in cells only exposed to UVB (Figure 3c). We observed an increase in $\mathrm{O}_{2}{ }^{\circ-}$ generation, with a significant plateau $10 \mathrm{~h}$ post-UVB irradiation compared to the control $(\mathrm{p}<0.001)$, and we detected a time-dependent decrease in the amount of CPDs after UVB irradiation. Zn (II) pretreatment changed both processes that were induced by UVB (Figure 3d). Our results showed that significantly less CPDs (by 19.64\%) were detected $3 \mathrm{~h}$ after UVB irradiation in cells pretreated with $\mathrm{Zn}$ (II) for $24 \mathrm{~h}$ compared to cells exposed only to UVB ( $\mathrm{p}=0.0082$ ). However, at $10 \mathrm{~h}$ post-UVB exposure, significant enhancement of superoxide generation was observed when comparing Zn (II) pre-treated, UVB-irradiated cells to cells only treated with UVB irradiation $(\mathrm{p}<0.001)$.

3.5. Zn (II) pre-exposure altered the type of cell death after UVB irradiation, without influencing the overall survival

To investigate the effect of reduced levels of CPDs but elevated $\mathrm{O}_{2}{ }^{--}$levels after Zn (II) pretreatment, flow cytometric apoptosis and EZ4U cell viability assays were used. We found that the cell survival did not change between $\mathrm{Zn}$ (II)-treated and control cells $24 \mathrm{~h}$ after UVB 
Metallomics

irradiation (Figure 4a). Regarding control cells, the percentage of proliferating cells was $88.69 \%$ and the viability of cells after UVB irradiation was decreased by $51.96 \%$. Regarding $\mathrm{Zn}$ (II) exposure the percentage of proliferating cells was $91.71 \%$, and $\mathrm{Zn}$ (II) pre-treatment did not impact the effect of UVB irradiation, the viability of cells was decreased by $50.64 \%$ (Figure $4 \mathrm{~b}$ ). On the other hand, Zn (II) pre-treatment significantly decreased the proportion of early apoptotic cells (Annexin $\mathrm{V}^{+} \mathrm{PI}^{-}$; by 5.94\%, 0.57-fold change, $\mathrm{p}=0.0286$ ) and significantly increased the population of late apoptotic plus necrotic cells (Annexin $\mathrm{V}^{+} \mathrm{PI}^{+}$and Annexin $\mathrm{V}^{-}$ $\mathrm{PI}^{+}$; by 4.61\%, 1.12-fold change, $\mathrm{p}=0.0026$ ) (Figure 4b).

\subsection{Zn (II) caused a transcriptional shift in the UVB-modulated expression of genes}

To determine the molecular mechanism behind the cellular response to the combined effects of $\mathrm{Zn}$ (II) and UVB exposure, we performed a TaqMan Low-Density Array analysis to characterise the gene expression changes in $\mathrm{HaCaT}$ cells pre-treated with $\mathrm{Zn}$ (II). We identified 39 differentially expressed genes in cells only submitted to UVB irradiation $6 \mathrm{~h}$ after exposure compared to non-irradiated control cells (Table 2; Supplementary 2). Twelve genes were expressed more than 2-fold higher in UVB-irradiated cells than in control cells, and TNF, PTGS2, and IL-8 showed the highest overexpression (>10-fold). We identified 27 genes that were down-regulated in UVB-irradiated cells compared to the control cells; MT1E was the most repressed (0.12-fold). Furthermore, MTF1 levels were significantly decreased compared to the control (0.32-fold). We observed a modest modulation in gene expression when comparing Zn (II) pre-treated, UVB-irradiated cells to those that were only UVBirradiated. Zn (II) pre-exposure mainly reduced UVB-induced HIPK2 mRNA suppression and caused little modification of POLB and RAD51 mRNA levels, whose relative gene expression levels were repressed following UVB irradiation $(<0.75$-fold $)$ but remained unchanged (0.76-1.5-fold change) when pre-treated with Zn (II). 


\section{Metallomics}

\section{Discussion}

The events involved in the regulation of zinc homeostasis are complex and incompletely understood ${ }^{24}$. In the skin, zinc is related to physiological functions, as shown from the consequences of zinc deficiency ${ }^{1,2}$. The use of zinc-containing topical therapeutics is widespread due to its clear benefit on cutaneous regeneration and on various inflammatory skin conditions ${ }^{3}$. UVB, the main harmful environmental factor in skin, induces intracellular zinc release in keratinocytes, suggesting a functional role of zinc in the UV stress response ${ }^{15}$, 16

Extracellular zinc is thought to enter the cell through plasma membrane zinc importers and then is transported via a muffler with high affinity for zinc (e.g., MT) to intracellular storage sites such as the endoplasmic reticulum ${ }^{25}$. Passive diffusion of zinc across cell membranes is not possible ${ }^{26}$. Bozym et al. ${ }^{27}$ investigated the effect of cell culture medium on the intracellular $\mathrm{Zn}$ (II) concentration and found that both the type of cell and the medium influence the intracellular free $\mathrm{Zn}$ (II) level during exposure to a certain concentration of $\mathrm{Zn}$ (II) and that the toxicity of supplemented Zn (II) must be carefully investigated. Previous experiments have shown that the exposure of $\mathrm{HaCaT}$ keratinocytes to $100 \mu \mathrm{M} \mathrm{ZnCl}_{2}$ was nontoxic to the skin cells ${ }^{28}$, and we have not found this concentration to be toxic in our experimental conditions. Based on the calculations of Bozym et al. ${ }^{27}, 100 \mu \mathrm{M} \mathrm{Zn}$ (II) treatment leads to an approximate 100-nM increase of intracellular $\mathrm{Zn}$ (II). We also investigated the mRNA expression of MT isoforms. More than 10 functional MT isoforms are present in humans and are classified into four groups; we analysed the mRNA expression of nine of the MT isoforms from the MT1 and MT2 groups in keratinocytes in our experiments ${ }^{29}$. We detected the expression of four isoforms, namely MT2A, MT1X, MT1E, and MT1F. $\mathrm{Zn}$ (II) treatment significantly increased the mRNA expression of all four MT isoforms and SLC30A1 (Table 1.). Specific antibodies against the MT protein isoforms are not available; therefore, a composite of MTI/II can only be investigated at the protein level. Western blot analysis demonstrated that $\mathrm{Zn}$ (II) treatment induced the production of MTI/II protein in a time-dependent manner (Figure 2a). In addition, we investigated the cellular localisation of MTs and found that MTs were present mostly in the nuclei of control cells, but after $24 \mathrm{~h}$ of treatment with Zn (II), we detected high amounts of MTs in the cytoplasm of the cells (data not shown). The variability of the localisation of MTs upon Zn (II) exposure may reflect the expression of MT isoforms with distinct function. Previously, we found high MTI/II protein expression in the nuclei of benign nevus cells, while high levels of MTI/II were present also 
in the cytoplasm of cells in malignant melanoma ${ }^{10}$. In the present study we found a significant proliferation advantage upon $100 \mu \mathrm{M} \mathrm{ZnCl}$ exposure, in accordance with a previous study ${ }^{28}$. We also tested the effect of $50 \mu \mathrm{M} \mathrm{ZnCl}_{2}$ treatment, but the change in proliferation was not significant. Although the effects of zinc on intracellular signalling events are not completely known, a positive impact of $\mathrm{Zn}$ (II) on cell proliferation might be attributed, at least in part, to the inhibition of phosphatases, leading to augmented protein tyrosine phosphorylation ${ }^{30}$. The proliferation advantage by $\mathrm{Zn}$ (II) treatment can also be a consequence of increased calcium uptake ${ }^{31}$ or up-regulated gene expression (e.g., NOTCH1, see Table 1) ${ }^{32,33}$. Interestingly, in aged skin, which is characterised by decreased epidermal renewal, the expression of MT is lower ${ }^{34}$.

The mechanism of action of zinc impact on cell signalling is not well understood ${ }^{25}$; herein, we found that zinc might affect reactive oxygen species (ROS)-sensitive signalling pathways. This is the first report demonstrating high expression of HMOX1 in cultured human keratinocytes upon nontoxic $\mathrm{Zn}$ (II) exposure (Figure 2b). The HMOX1 gene encodes an important member of the phase-II enzymes, which have cytoprotective roles in ROS scavenging. Furthermore, HMOX1 was shown to prevent cell death and to have a role in the regulation of inflammation ${ }^{35-37}$. Nontoxic generation of $\mathrm{O}_{2}{ }^{--}$with subsequent $\mathrm{H}_{2} \mathrm{O}_{2}$ release was detected during nontoxic $\mathrm{Zn}$ (II) exposure (Figure $3 \mathrm{a}$ and $3 \mathrm{~b}$ ) and could explain the HMOX1 expression. Although Zn (II) itself is reported to be an inducer of oxidative stress by promoting mitochondrial and extra-mitochondrial production of ROS ${ }^{15}$, the generation of ROS at a nontoxic level upon Zn (II) exposure/release has not been described. Nevertheless, $\mathrm{O}_{2}{ }^{--}$-producing $\mathrm{NAD}(\mathrm{P}) \mathrm{H}$ oxidases are activated in response to growth factors and oncogenes, and enhanced cell proliferation was observed upon ROS-inducing, low-dose photodynamic treatment ${ }^{38-42}$. Therefore, simultaneous increases in cell proliferation and ROS levels are not conflicting. In addition, NADPH oxidase mediated the induction of NFKB and HMOX1 in human colon cancer cells ${ }^{43}$ without inducing cell death. Furthermore, the immune response can be redox-regulated ${ }^{44}$, and we have observed down-regulation of some proinflammatory mediators, such as IL8 and PTGS2, which are partly regulated by redoxsensitive transcription factors (e.g., AP-1) ${ }^{45}$.

UVB exposure is the primary risk factor in skin-tumour development ${ }^{46}$. A role of zinc in the mechanism of UVB-induced cell death has already been proposed. Stork et al. ${ }^{15}$ described that the elevation of intracellular zinc levels after UVB irradiation is proportional to the fraction of dying or dead cells, and they concluded that UVB-induced zinc release may be an important step in UVB-induced cell death pathways. The consequences of UVB-induced 
direct (primarily CPDs) and indirect (free radical generation) DNA damage are cell cycle arrest, DNA repair, and the induction of cell death pathways causing sunburn, inflammation, immunosuppression, and melanogenesis in the skin ${ }^{47}$. We measured both the CPD level and superoxide generation (Figure 3c and 3d). Due to DNA repair processes, the amount of CPDs was decreased with time, and cells with unrepaired DNA damage were eliminated by apoptosis (Figure 4b). Similar to the results of Saito et al., pre-treatment of cells with Zn (II) for $24 \mathrm{~h}$ was not sufficient to improve cell survival (Figure $4 \mathrm{a}$ ), although the level of induced CPD was lower in these cells $3 \mathrm{~h}$ after UVB irradiation ${ }^{48}$. We assume that MT could exert some effect on CPD formation because partial translocation of MTs to the nucleus was observed $3 \mathrm{~h}$ after UVB irradiation (data not shown). Nevertheless, when further analysing cell death at $24 \mathrm{~h}$ post-UVB irradiation, when UVB-induced apoptosis is maximal ${ }^{49}$, we found that the fraction of early apoptotic cells decreased, while the fraction of late apoptotic plus necrotic cells increased in $\mathrm{Zn}$ (II) pre-treated cells (Figure $4 \mathrm{~b}$ ). In the context of our results, the elevation of intracellular zinc levels after UVB irradiation that was described by Stork et al. was proportional to the fraction of dying or dead cells ${ }^{15}$. When investigating the course of ROS production, the increase in superoxide production upon UVB treatment occurred at a maximum of $10 \mathrm{~h}$, but unexpectedly, this was augmented by $\mathrm{Zn}$ (II) preexposure (Figure 3c). It has recently been described that a vicious circle of ROS-induced zinc release and zinc-driven mitochondrial ROS production is an important neuronal cell death mechanism ${ }^{50}$. On the other hand, it has been reported that the induction of a type of cell death other than apoptosis in cancer cells might increase the immunogenic potential of cell death ${ }^{51}$, 52 . Whether a change in the death process upon Zn (II) pre-exposure can affect the immune response to UV-damaged cells, which would impact the development of various pathologies, e.g., autoimmunity or cancers, must be further studied.

Zinc is redox inert metal. Observed changes in ROS might be attributed to the molecular effects of $\mathrm{Zn}$ (II) interactions with cysteinyl thiols, which alters protein functionality and thereby their reactivity and participation in redox reactions ${ }^{8}$. It seems worthy to further examine the role of zinc in skin because further clarification of this issue can affect our thinking about the pathogenesis of skin diseases and can help identify new therapeutic targets. 


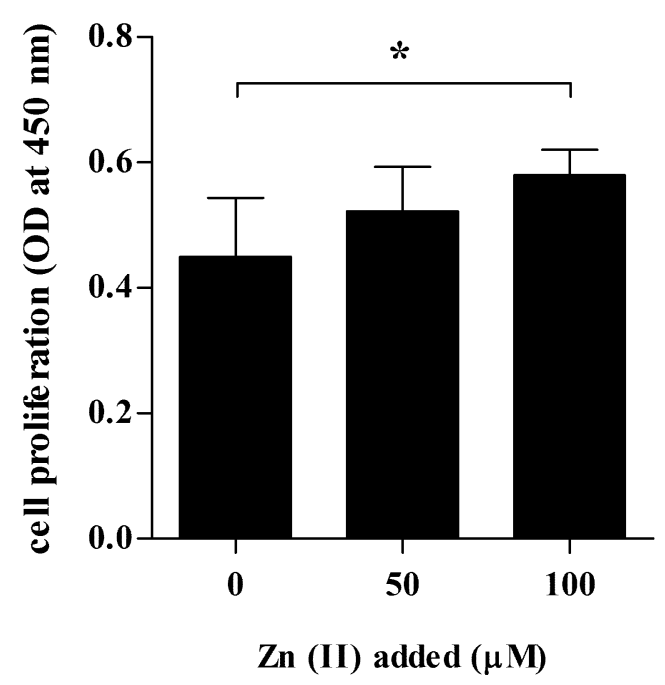

Figure 1. Effect of Zn (II) exposure on cell proliferation in HaCaT keratinocytes.

$\mathrm{HaCaT}$ cells were treated with 50 or $100 \mu \mathrm{M} \mathrm{ZnCl}_{2}$ for $72 \mathrm{~h}$, and cell proliferation was measured by an EZ4U assay. The data were derived from three independent experiments and are presented as the mean \pm SEM. An asterisk indicates a significant difference between $\mathrm{ZnCl}_{2}$-treated and control cells at $\mathrm{p}<0.05$, with a 2-tailed Student's $\mathrm{t}$ test.

A



B

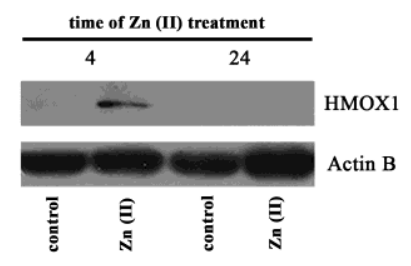

Figure 2. Effect of $\mathrm{Zn}$ (II) exposure on the protein expression of MTI/II and HMOX1

$\mathrm{HaCaT}$ cells were treated with $100 \mu \mathrm{M} \mathrm{ZnCl}_{2}$ for $4,24,48$ or $72 \mathrm{~h}$, and western blotting $\mathbf{A}$ for MTI/II and B for HMOX1 were performed. Actin B protein expression was used as a reference; the representative data of three independent experiments are shown. 
A

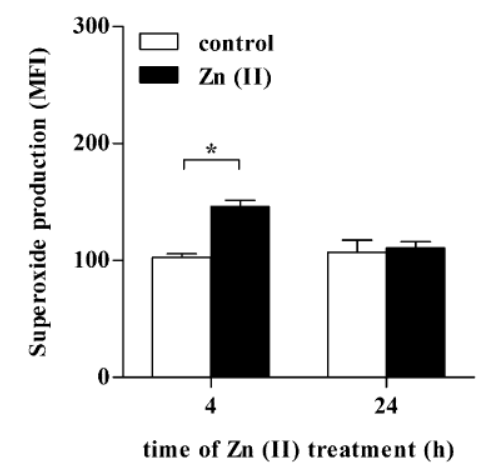

C



B

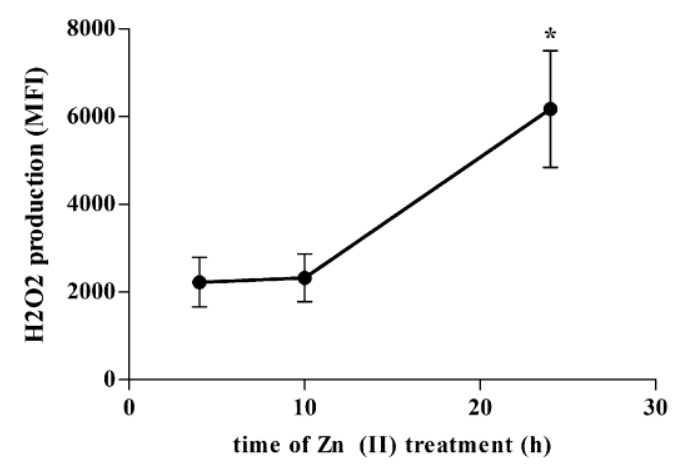

D

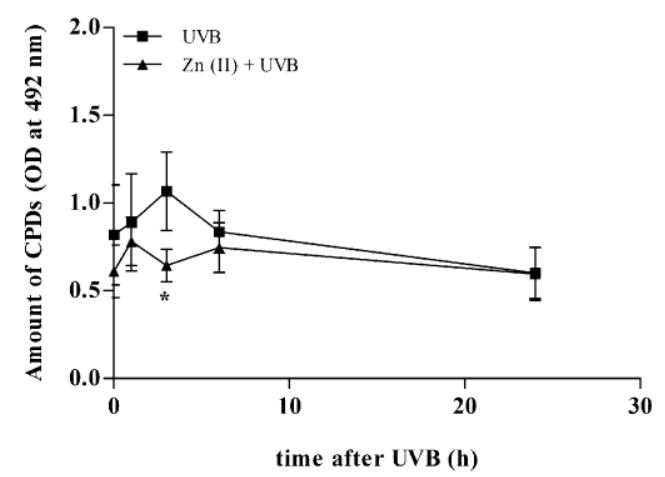

Figure 3. Effect of $\mathrm{Zn}$ (II) exposure on the production of reactive oxygen species and on the UVB-induced DNA-damage response

$\mathrm{HaCaT}$ cells were treated with $100 \mu \mathrm{M} \mathrm{ZnCl}$ for 4 or $24 \mathrm{~h}$ and $\mathbf{A}$ the production of $\mathrm{O}_{2}{ }^{--}$was analysed using a flow cytometry-based dihydroethidium assay. B Cells were exposed to 100 $\mu \mathrm{M} \mathrm{ZnCl}$ for 4,10 or $24 \mathrm{~h}$, and the production of $\mathrm{H}_{2} \mathrm{O}_{2}$ was measured using a fluorimetricbased Amplex Red assay. The MFI values of untreated cells were subtracted from those of the treated cells. C HaCaT cells were treated with $100 \mu \mathrm{M} \mathrm{ZnCl}_{2}$ for $24 \mathrm{~h}$ followed by $20 \mathrm{~mJ} / \mathrm{cm}^{2}$ UVB irradiation, and the amount of CPDs was determined at 0, 1, 3, 6, and $24 \mathrm{~h}$ after UVB irradiation using a CPD-specific ELISA. The OD values of untreated cells were subtracted from those of the treated cells. $D$ The production of $\mathrm{O}_{2}{ }^{--}$was measured by a flow cytometrybased dihydroethidium assay $1,4,10$, and $24 \mathrm{~h}$ after UVB treatment.

The data were derived from three independent experiments and are presented as the mean \pm SEM. An asterisk indicates a significant difference between $\mathrm{ZnCl}_{2}$-treated and control cells $(A, B)$ or between the $\mathrm{ZnCl}_{2}$ and UVB combination treatment and cells only exposed to UVB $(\mathbf{C}, \mathbf{D})$ at $\mathrm{p}<0.05$, using a 2-tailed Student's t test. 
Metallomics

A

B
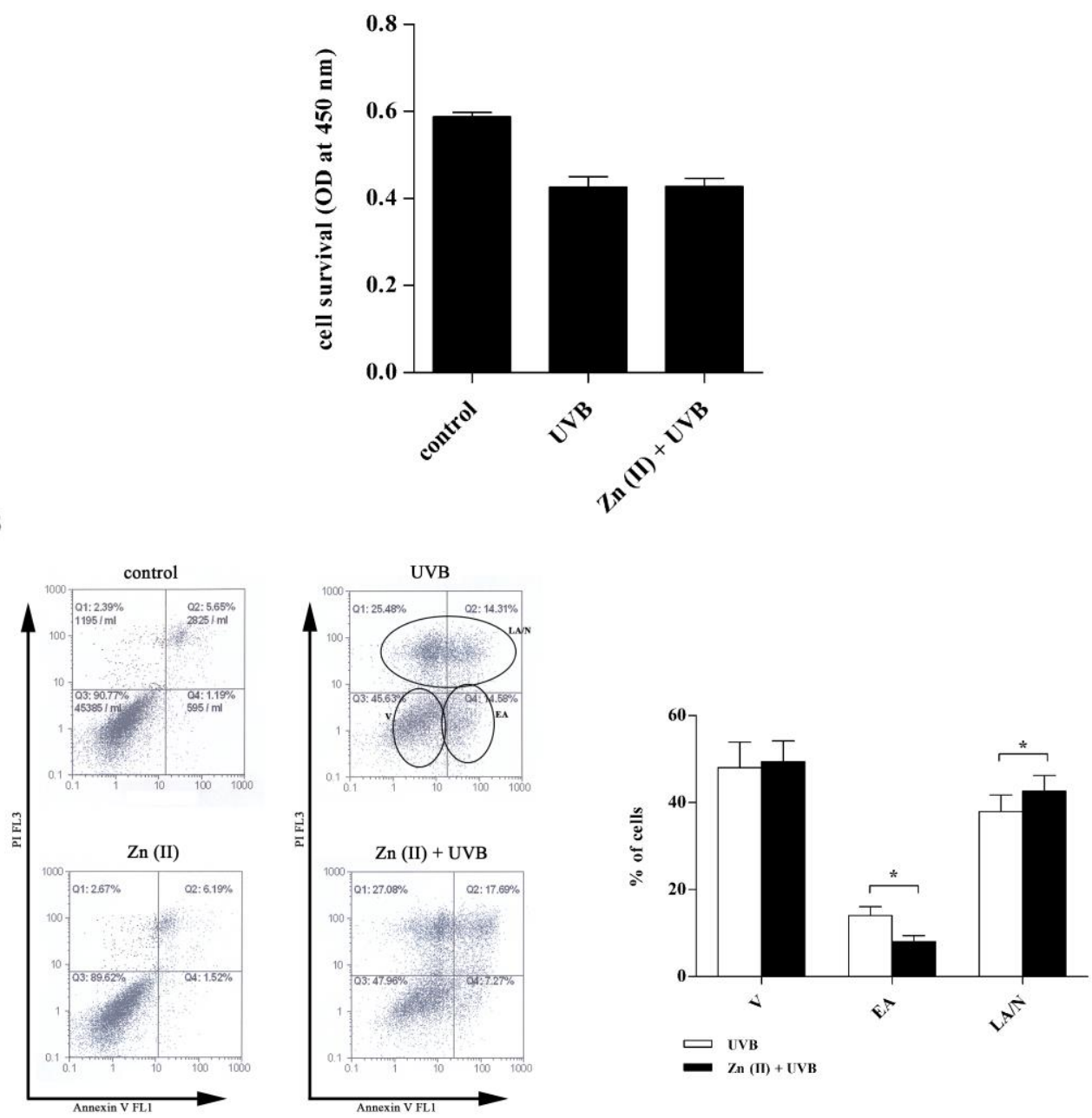

Figure 4. Effect of Zn (II) exposure on the UVB-induced cell death

HaCaT cells were treated with $100 \mu \mathrm{M} \mathrm{ZnCl}$ for $24 \mathrm{~h}$ followed by $20 \mathrm{~mJ} / \mathrm{cm}^{2} \mathrm{UVB}$ irradiation, and A cell survival was measured using an EZ4U assay $24 \mathrm{~h}$ after UVB. B The rate of apoptosis was investigated by flow cytometry using Annexin $\mathrm{V}$ and propidium iodide staining $24 \mathrm{~h}$ after UVB irradiation. V=viability; EA=early apoptosis; LA/N=late apoptosis plus necrosis. The data were derived from three independent experiments and are presented as the mean \pm SEM, $p$ values were calculated by 2 -tailed Student's $t$ test. 
Metallomics

\begin{tabular}{|l|l|l|}
\hline \multirow{2}{*}{ Gene Symbol } & fold change $\left(2^{\text {-ddCt }}\right)$ \\
\cline { 2 - 3 } & 4 h after Zn (II) treatment & 24 h after Zn (II) treatment \\
\hline MT1F & $\mathbf{4 0 . 8 6}$ & $\mathbf{1 2 . 9 2}$ \\
\hline MT1X & $\mathbf{1 7 . 3 4}$ & $\mathbf{3 . 2 4}$ \\
\hline HMOX1 & $\mathbf{1 5 . 3 3}$ & $\mathbf{1 . 5 6}$ \\
\hline MT1E & $\mathbf{7 . 3 0}$ & $\mathbf{2 . 1 2}$ \\
\hline MT2A & $\mathbf{6 . 4 4}$ & $\mathbf{3 . 0 3}$ \\
\hline SLC30A1 & $\mathbf{6 . 4 1}$ & $\mathbf{2 . 4 8}$ \\
\hline NOTCH1 & $\mathbf{1 . 4 7}$ & 1.06 \\
\hline PTGS2 & $\mathbf{0 . 6 8}$ & 1.01 \\
\hline IL8 & $\mathbf{0 . 6 3}$ & 0.92 \\
\hline CYP1B1 & $\mathbf{0 . 6 3}$ & 1.32 \\
\hline
\end{tabular}

Table 1. Differentially expressed genes upon $\mathrm{Zn}$ (II) treatment

The relative gene expression of the listed genes was measured in HaCaT cells treated with $100 \mu \mathrm{M} \mathrm{ZnCl}_{2}$ relative to untreated cells by TLDA. Values greater than 1.5 but less than 0.75 are highlighted in bold and indicate significant t-test results at $\mathrm{p}<0.05$, using a 2-tailed Student's t test. 
Metallomics



Table 2. Effect of $\mathrm{Zn}$ (II) pre-treatment on transcriptional changes induced by UVB irradiation

Relative gene expression was measured $6 \mathrm{~h}$ after UVB irradiation in HaCaT cells exposed to $20 \mathrm{~mJ} / \mathrm{cm}^{2} \mathrm{UVB}$ or pre-treated with $100 \mu \mathrm{M} \mathrm{ZnCl}_{2}$ for $24 \mathrm{~h}$ and then UVB irradiated relative to untreated cells, using TLDA. 


\section{Metallomics}

\begin{tabular}{|c|c|c|}
\hline Gene Symbol & Assay ID & Gene Name \\
\hline $\mathrm{ACTB}^{1}$ & Hs99999903_m1 & actin, beta \\
\hline $\mathrm{AKT} 1^{\mathrm{b}}$ & Hs00178289_m1 & v-akt murine thymoma viral oncogene homolog 1 \\
\hline $\mathrm{APC}^{\mathrm{b}}$ & Hs01568269_m1 & Adenomatous Polyposis Coli \\
\hline $\mathrm{APEX}^{\mathrm{d}}$ & Hs00172396_m1 & $\begin{array}{l}\text { APEX nuclease (multifunctional DNA repair } \\
\text { enzyme) } 1\end{array}$ \\
\hline $\mathrm{ATF}^{\mathrm{a}, \mathrm{b}}$ & Hs00231069_m1 & activating transcription factor 3 \\
\hline $\mathrm{ATM}^{\mathrm{b}}$ & Hs01112307_m1 & ataxia telangiectasia mutated \\
\hline $\mathrm{ATR}^{\mathrm{b}}$ & Hs00354807_m1 & ataxia telangiectasia and $\operatorname{Rad} 3$ related \\
\hline $\mathrm{BAD}^{\mathrm{b}}$ & Hs00188930_m1 & BCL2-associated agonist of cell death \\
\hline $\mathrm{BCL} 2^{\mathrm{b}}$ & Hs00608023_m1 & B-cell CLL/lymphoma 2 \\
\hline BCL2L1 ${ }^{\mathrm{b}}$ & Hs00236329_m1 & BCL2-like 1 \\
\hline C11orf31 & Hs00415057_m1 & chromosome 11 open reading frame 31 \\
\hline CCNE1 ${ }^{b}$ & Hs01026536_m1 & cyclin E1 \\
\hline $\mathrm{CCNF}^{\mathrm{b}}$ & Hs00171049_m1 & cyclin $\mathrm{F}$ \\
\hline $\mathrm{CDKN}_{1 \mathrm{~A}}{ }^{\mathrm{b}}$ & Hs00355782_m1 & cyclin-dependent kinase inhibitor 1A (p21, Cip1) \\
\hline CEBPA $^{\text {b, h }}$ & Hs00269972_s1 & CCAAT/enhancer binding protein (C/EBP), alpha \\
\hline $\mathrm{CEBPB}^{\mathrm{b}}$ & Hs00270923_s1 & CCAAT/enhancer binding protein $(\mathrm{C} / \mathrm{EBP})$, beta \\
\hline CHEK $1^{b}$ & Hs00967506_m1 & CHK1 checkpoint homolog (S. pombe) \\
\hline $\mathrm{CHEK} 2^{\mathrm{b}}$ & Hs00200485_m1 & CHK2 checkpoint homolog (S. pombe) \\
\hline CYP1A $1^{\mathrm{k}}$ & Hs00153120_m1 & $\begin{array}{l}\text { cytochrome } \mathrm{P} 450, \text { family } 1, \text { subfamily } \mathrm{A} \text {, } \\
\text { polypeptide } 1\end{array}$ \\
\hline CYP1B $1^{\mathrm{k}}$ & Hs00164383_m1 & $\begin{array}{l}\text { cytochrome } \mathrm{P} 450, \text { family } 1, \text { subfamily } \mathrm{B} \text {, } \\
\text { polypeptide } 1\end{array}$ \\
\hline $\mathrm{DDB} 1^{\mathrm{c}}$ & Hs00172410_m1 & damage-specific DNA binding protein $1,127 \mathrm{kDa}$ \\
\hline
\end{tabular}


Metallomics

\begin{tabular}{|c|c|c|}
\hline $\mathrm{DDB} 2^{\mathrm{c}}$ & Hs03044953_m1 & damage-specific DNA binding protein $2,48 \mathrm{kDa}$ \\
\hline DDIT $^{b}$ & Hs01090850_m1 & DNA-damage-inducible transcript 3 \\
\hline $\mathrm{ERCC} 1^{\mathrm{c}}$ & Hs01012158_m1 & $\begin{array}{l}\text { excision repair cross-complementing rodent repair } \\
\text { deficiency, complementation group } 1 \text { (includes } \\
\text { overlapping antisense sequence) }\end{array}$ \\
\hline $\mathrm{ERCC} 2^{\mathrm{c}}$ & Hs00361161_m1 & $\begin{array}{l}\text { excision repair cross-complementing rodent repair } \\
\text { deficiency, complementation group } 2\end{array}$ \\
\hline $\mathrm{ERCC}^{\mathrm{c}}$ & Hs01554450_m1 & $\begin{array}{l}\text { excision repair cross-complementing rodent repair } \\
\text { deficiency, complementation group } 3 \text { (xeroderma } \\
\text { pigmentosum group B complementing) }\end{array}$ \\
\hline $\mathrm{ERCC}^{\mathrm{c}}$ & Hs00193342_m1 & $\begin{array}{l}\text { excision repair cross-complementing rodent repair } \\
\text { deficiency, complementation group } 4\end{array}$ \\
\hline $\mathrm{ERCC}^{\mathrm{c}}$ & Hs00164482_m1 & $\begin{array}{l}\text { excision repair cross-complementing rodent repair } \\
\text { deficiency, complementation group } 5\end{array}$ \\
\hline FOS $^{b}$ & Hs00170630_m1 & FBJ murine osteosarcoma viral oncogene homolog \\
\hline${\text { GADD } 45 B^{b}}^{b}$ & Hs00169587_m1 & growth arrest and DNA-damage-inducible, beta \\
\hline $\mathrm{GAPDH}^{1}$ & Hs99999905_m1 & glyceraldehyde-3-phosphate dehydrogenase \\
\hline GLI1 $^{\mathrm{j}}$ & Hs01110766_m1 & GLI family Zinc (II) finger 1 \\
\hline $\mathrm{HBEGF}^{\mathrm{a}, \mathrm{b}}$ & Hs00181813_m1 & heparin-binding EGF-like growth factor \\
\hline HIPK $2^{b}$ & Hs00179759_m1 & homeodomain interacting protein kinase 2 \\
\hline $\mathrm{HMOX}{ }^{\mathrm{i}}$ & Hs01110250_m1 & heme oxygenase (decycling) 1 \\
\hline HSPA6 $^{\mathrm{k}}$ & Hs00275682_s1 & heat shock 70kDa protein 6 (HSP70B') \\
\hline $\mathrm{HSPD}^{\mathrm{k}}$ & Hs01941522_u1 & heat shock 60kDa protein 1 (chaperonin) \\
\hline IGF1R ${ }^{b}$ & Hs00609566_m1 & insulin-like growth factor 1 receptor \\
\hline IL10 $^{\text {a }}$ & Hs00961622_m1 & interleukin 10 \\
\hline $\mathrm{IL}_{1 \mathrm{~B}}^{\mathrm{a}}$ & Hs01555410_m1 & interleukin 1 , beta \\
\hline $\mathrm{IL}_{1 \mathrm{RN}}^{\mathrm{a}}$ & Hs00893626_m1 & interleukin 1 receptor antagonist \\
\hline IL $^{\mathrm{a}}$ & Hs00174103_m1 & interleukin 8 \\
\hline $\mathrm{ITCH}^{\mathrm{b}}$ & Hs00395201_m1 & itchy E3 ubiquitin protein ligase homolog (mouse) \\
\hline $\mathrm{JUN}^{\mathrm{b}}$ & Hs00277190_s1 & jun proto-oncogene \\
\hline KRT10 & Hs00166289 m1 & keratin 10 \\
\hline
\end{tabular}


Metallomics

\begin{tabular}{|c|c|c|}
\hline $\mathrm{LCN} 2^{\mathrm{h}, \mathrm{i}}$ & Hs01008571_m1 & lipocalin 2 \\
\hline $\operatorname{MDM} 2^{b}$ & Hs00234753_m1 & Mdm2 p53 binding protein homolog (mouse) \\
\hline $\mathrm{MGMT}^{\mathrm{k}}$ & Hs01037698_m1 & O-6-methylguanine-DNA methyltransferase \\
\hline MMP9 $^{\mathrm{a}}$ & Hs00234579_m1 & $\begin{array}{l}\text { matrix metallopeptidase } 9 \text { (gelatinase } \mathrm{B}, 92 \mathrm{kDa} \\
\text { gelatinase, } 92 \mathrm{kDa} \text { type IV collagenase) }\end{array}$ \\
\hline $\mathrm{MSH}_{2}{ }^{\mathrm{e}}$ & Hs00953523_m1 & $\begin{array}{l}\text { mutS homolog } 2 \text {, colon cancer, nonpolyposis type } 1 \\
\text { (E. coli) }\end{array}$ \\
\hline $\mathrm{MSH6}^{\mathrm{e}}$ & Hs00264721_m1 & mutS homolog 6 (E. coli) \\
\hline MT1A $^{\mathrm{g}, \mathrm{h}}$ & Hs00831826_s1 & metallothionein $\mathbf{1 A}$ \\
\hline MT1B $^{\mathrm{g}, \mathrm{h}}$ & Hs00538861_m1 & metallothionein 1B \\
\hline${\mathrm{MT} 1 \mathrm{E}^{\mathrm{g}, \mathrm{h}}}$ & Hs01938284_g1 & metallothionein $1 \mathrm{E}$ \\
\hline${\mathrm{MT} 1 \mathrm{~F}^{\mathrm{g}, \mathrm{h}}}$ & Hs00744661_sH & metallothionein $1 \mathrm{~F}$ \\
\hline MT1G $^{\mathrm{g}, \mathrm{h}}$ & Hs02578922_Gh & metallothionein 1G \\
\hline MT1H $^{\mathrm{g}, \mathrm{h}}$ & Hs00823168_g1 & metallothionein $\mathbf{1 H}$ \\
\hline MT1M $^{\mathrm{g}, \mathrm{h}}$ & Hs00828387_g1 & metallothionein $1 \mathrm{M}$ \\
\hline MT1X $X^{\mathrm{g}, \mathrm{h}}$ & Hs00745167_sH & metallothionein $1 \mathrm{X}$ \\
\hline $\mathrm{MT} 2 \mathrm{~A}^{\mathrm{g}, \mathrm{h}}$ & Hs01591333_g1 & metallothionein $2 \mathrm{~A}$ \\
\hline $\mathrm{MTF}^{\mathrm{g}}$ & Hs00232306_m1 & metal-regulatory transcription factor 1 \\
\hline NOTCH1 $1^{\mathrm{h}, \mathrm{j}}$ & Hs01062014_m1 & notch 1 \\
\hline NTHL1 ${ }^{d}$ & Hs00959764_m1 & nth endonuclease III-like 1 (E. coli) \\
\hline OGG1 ${ }^{d}$ & Hs00213454_m1 & 8-oxoguanine DNA glycosylase \\
\hline PARP1 ${ }^{d}$ & Hs00242302_m1 & poly (ADP-ribose) polymerase 1 \\
\hline PCNA $^{c, d, e}$ & Hs00427214_g1 & proliferating cell nuclear antigen \\
\hline PGK $1^{1}$ & Hs00943178_g1 & phosphoglycerate kinase 1 \\
\hline POLB $^{d}$ & Hs01099715_m1 & polymerase (DNA directed), beta \\
\hline $\mathrm{PTGS}^{\mathrm{a}}$ & Hs00153133_m1 & $\begin{array}{l}\begin{array}{l}\text { prostaglandin-endoperoxide } \\
\text { (prostaglandin G/H synthase and cyclooxygenase) }\end{array} \\
\end{array}$ \\
\hline $\mathrm{RAD}_{23 \mathrm{~B}}{ }^{\mathrm{c}}$ & Hs00234102_m1 & RAD23 homolog B (S. cerevisiae) \\
\hline RAD5 $1^{\mathrm{f}}$ & Hs00153418_m1 & $\begin{array}{l}\text { RAD51 homolog (RecA homolog, E. coli) (S. } \\
\text { cerevisiae) }\end{array}$ \\
\hline${\text { RAD } 52^{f}}^{f}$ & Hs00172536_m1 & RAD52 homolog (S. cerevisiae) \\
\hline $\mathrm{RPA}^{\mathrm{c}, \mathrm{f}}$ & Hs00161419_m1 & replication protein $\mathrm{A} 1,70 \mathrm{kDa}$ \\
\hline $\mathbf{S 1 0 0 A} 7^{\mathrm{a}, \mathrm{j}}$ & Hs00161488_m1 & S100 calcium binding protein A7 \\
\hline $\mathrm{SDHA}^{1}$ & Hs00188166_m1 & $\begin{array}{l}\text { succinate dehydrogenase complex, subunit } \mathrm{A} \text {, } \\
\text { flavoprotein }(\mathrm{Fp})\end{array}$ \\
\hline $\mathrm{SKIL}^{\mathrm{b}}$ & Hs01045418_m1 & SKI-like oncogene \\
\hline SLC30A $1^{\mathrm{g}, \mathrm{h}}$ & Hs00253602_m1 & $\begin{array}{l}\begin{array}{l}\text { solute carrier family } 30 \text { (Zinc (II) transporter), } \\
\text { member } 1\end{array} \\
\end{array}$ \\
\hline
\end{tabular}


Metallomics

\begin{tabular}{|c|c|c|}
\hline SMUG1 ${ }^{\mathrm{d}}$ & Hs00204820_m1 & $\begin{array}{l}\text { single-strand-selective monofunctional uracil-DNA } \\
\text { glycosylase } 1\end{array}$ \\
\hline SNAI $^{\mathrm{a}}$ & Hs00950344_m1 & snail homolog 2 (Drosophila) \\
\hline $\mathbf{T N F}^{\mathrm{a}}$ & Hs00174128_m1 & tumor necrosis factor \\
\hline TNFAIP $^{\mathrm{a}}$ & Hs00234713_m1 & tumor necrosis factor, alpha-induced protein 3 \\
\hline $\mathrm{TP}^{\mathrm{b}}{ }^{\mathrm{b}}$ & Hs01034249_m1 & tumor protein $\mathrm{p} 53$ \\
\hline $\mathrm{TP}^{\mathrm{C}} 3^{\mathrm{b}}$ & Hs01056230_m1 & tumor protein $\mathrm{p} 73$ \\
\hline TREX $1^{\mathrm{e}}$ & Hs03055245_s1 & three prime repair exonuclease 1 \\
\hline TRIM $26^{\mathrm{a}}$ & Hs00758189_m1 & tripartite motif-containing 26 \\
\hline $\mathrm{TXN}^{\mathrm{i}}$ & Hs01555212_g1 & thioredoxin \\
\hline $\mathrm{UNG}^{\mathrm{d}}$ & Hs00422172_m1 & uracil-DNA glycosylase \\
\hline VEGFC $^{\mathrm{a}}$ & Hs00153458_m1 & vascular endothelial growth factor $\mathrm{C}$ \\
\hline $\mathrm{XPA}^{\mathrm{c}}$ & Hs00166045_m1 & xeroderma pigmentosum, complementation group A \\
\hline $\mathrm{XPC}^{\mathrm{c}}$ & Hs01104206_m1 & xeroderma pigmentosum, complementation group C \\
\hline $\mathrm{XRCC} 1^{\mathrm{d}}$ & Hs00959834_m1 & $\begin{array}{l}\text { X-ray repair complementing defective repair in } \\
\text { Chinese hamster cells } 1\end{array}$ \\
\hline $\mathrm{XRCC} 2^{\mathrm{f}}$ & Hs03044154_m1 & $\begin{array}{l}\text { X-ray repair complementing defective repair in } \\
\text { Chinese hamster cells } 2\end{array}$ \\
\hline $\mathrm{XRCC}^{\mathrm{f}}$ & Hs00193725_m1 & $\begin{array}{l}\text { X-ray repair complementing defective repair in } \\
\text { Chinese hamster cells } 3\end{array}$ \\
\hline $\mathrm{XRCC}^{\mathrm{f}}$ & Hs00995282_g1 & $\begin{array}{l}\text { X-ray repair complementing defective repair in } \\
\text { Chinese hamster cells } 6\end{array}$ \\
\hline $\mathrm{ZNRD}^{\mathrm{k}}$ & Hs00205908_m1 & Zinc ribbon domain containing 1 \\
\hline
\end{tabular}

Supplementary 1. List of selected genes for TaqMan Low-Density Array analysis

Undetermined genes are highlighted in bold.

${ }^{\mathrm{a}}$ Inflammation

${ }^{\mathrm{b}}$ DNA-damage response

${ }^{\mathrm{c}}$ Nucleotide excision repair

${ }^{\mathrm{d}}$ Base excision repair

${ }^{\mathrm{e}}$ Mismatch repair

${ }^{\mathrm{f}}$ Double strand break repair

${ }^{\mathrm{g}}$ Zinc homeostasis

${ }^{\mathrm{h}}$ Genes containing MRE sites

${ }^{\mathrm{i}}$ Oxidative stress

${ }^{\mathrm{j}}$ Keratinocyte proliferation/differentiation, cell survival

${ }^{\mathrm{k}}$ Others: ZNRD1, MGMT, HSPA6 (HSP70B), HSPD1 (HSP60), CYP1A1, CYP1B1 


\section{Metallomics}

${ }^{1}$ Housekeeping genes used for normalisation 
Metallomics

\begin{tabular}{|c|c|c|c|c|}
\hline \multirow[b]{2}{*}{ Gene Symbol } & \multicolumn{2}{|l|}{ UVB } & \multicolumn{2}{|l|}{ Zinc (II) + UVB } \\
\hline & fold change $\left(2^{-\mathrm{ddCt}}\right)$ & $\mathrm{p}$ value $^{1}$ & fold change $\left(2^{-\mathrm{ddCt}}\right)$ & $\mathrm{p}$ value $^{1}$ \\
\hline TNF & 28,83 & 0,05815 & 24,37 & 0,014558 \\
\hline PTGS2 & 19,39 & 0,052279 & 18,10 & 0,004363 \\
\hline IL8 & 18,26 & 0,011145 & 21,04 & 0,00227 \\
\hline ATF3 & 9,30 & 0,026083 & 10,62 & 0,020249 \\
\hline $\mathrm{JUN}^{2}$ & 8,68 & ns & 8,21 & 0,050386 \\
\hline FOS $^{2}$ & 6,04 & $\mathrm{~ns}$ & 7,10 & $\mathrm{~ns}$ \\
\hline GADD45B & 5,85 & 0,005414 & 6,57 & 0,012406 \\
\hline $\mathrm{CDKN}_{1 \mathrm{~A}^{2}}$ & 4,21 & ns & 4,11 & 0,037189 \\
\hline CCNE1 & 3,67 & 0,044125 & 4,56 & 0,022938 \\
\hline SNAI2 $^{2}$ & 3,04 & ns & 3,42 & 0,003713 \\
\hline HBEGF & 2,71 & 0,001709 & 2,79 & 0,00898 \\
\hline $\mathrm{IL}_{\mathrm{B}}{ }^{2}$ & 2,53 & ns & 2,43 & 0,018241 \\
\hline DDIT3 & 1,78 & $\mathrm{~ns}$ & 1,97 & 0,044236 \\
\hline CYP1A1 & 1,62 & 0,042759 & 1,76 & 0,025693 \\
\hline CEBPA & 1,61 & 0,024664 & 1,66 & $\mathrm{~ns}$ \\
\hline SLC30A1 & 1,28 & $\mathrm{~ns}$ & 2,94 & 0,032076 \\
\hline MT1X & 1,15 & $\mathrm{~ns}$ & 4,33 & 0,01818 \\
\hline MT2A & 1,14 & ns & 3,89 & $5,58 \mathrm{E}-05$ \\
\hline MT1F & 0,78 & $\mathrm{~ns}$ & 21,92 & 0,000983 \\
\hline DDB2 & 0,74 & 0,035138 & 0,84 & ns \\
\hline ERCC2 & 0,71 & 0,002939 & 0,73 & 0,041664 \\
\hline NTHL1 & 0,71 & 0,031694 & 0,77 & ns \\
\hline RAD51 & 0,70 & 0,013263 & 0,85 & ns \\
\hline CHEK1 & 0,64 & 0,053186 & 0,72 & 0,019469 \\
\hline SMUG1 & 0,60 & $\mathrm{~ns}$ & 0,58 & 0,015714 \\
\hline TREX1 & 0,59 & 0,044764 & 0,64 & 0,032647 \\
\hline POLB & 0,56 & 0,006388 & 0,77 & ns \\
\hline CHEK2 & 0,55 & 0,014411 & 0,54 & 0,024618 \\
\hline ERCC5 & 0,51 & 0,040806 & 0,57 & 0,014313 \\
\hline MSH2 & 0,50 & 0,010779 & 0,54 & 0,004747 \\
\hline ERCC4 & 0,50 & 0,013892 & 0,55 & 0,000433 \\
\hline ERCC3 & 0,49 & 0,017928 & 0,48 & 0,003888 \\
\hline XRCC3 & 0,46 & 0,009467 & 0,46 & 0,00588 \\
\hline HIPK2 & 0,46 & 0,015698 & 0,74 & ns \\
\hline ITCH & 0,45 & 0,005814 & 0,47 & 0,00756 \\
\hline TRIM26 & 0,42 & 0,001248 & 0,47 & 0,000815 \\
\hline ATM & 0,41 & 0,009832 & 0,44 & 0,000551 \\
\hline IGF1R & 0,38 & 0,005486 & 0,39 & 0,000444 \\
\hline XPC & 0,37 & 0,002325 & 0,40 & 0,005501 \\
\hline BCL2L1 & 0,36 & 0,00826 & 0,37 & 0,008226 \\
\hline ATR & 0,36 & 0,005014 & 0,38 & 0,001731 \\
\hline
\end{tabular}


Metallomics

\begin{tabular}{|l|l|c|l|c|}
\hline MSH6 & 0,35 & 0,000764 & 0,41 & 0,011031 \\
\hline RAD52 & 0,33 & 0,001544 & 0,39 & 0,00087 \\
\hline MTF1 & 0,32 & 0,013172 & 0,33 & 0,00492 \\
\hline MDM2 & 0,30 & 0,00186 & 0,33 & 0,001146 \\
\hline TP73 & 0,28 & 0,005793 & 0,25 & 0,001074 \\
\hline VEGFC & 0,27 & 0,003256 & 0,27 & 0,001116 \\
\hline XRCC2 & 0,25 & 0,001383 & 0,26 & 0,000498 \\
\hline NOTCH1 & 0,23 & 0,001808 & 0,26 & 0,000788 \\
\hline SKIL & 0,23 & 0,001938 & 0,27 & 0,000269 \\
\hline APC & 0,20 & 0,007314 & 0,20 & 0,006341 \\
\hline BCL2 & 0,18 & 0,000877 & 0,12 & 0,002252 \\
\hline CCNF & 0,17 & 0,000928 & 0,21 & 0,001193 \\
\hline MT1E & 0,12 & 0,000225 & 0,30 & 0,002777 \\
\hline
\end{tabular}

Supplementary 2. Effect of Zn (II) pre-treatment on transcriptional changes induced by

\section{UVB irradiation}

The relative gene expression in HaCaT cells exposed to $20 \mathrm{~mJ} / \mathrm{cm}^{2} \mathrm{UVB}$ for $6 \mathrm{~h}$ or pre-treated with $100 \mu \mathrm{M} \mathrm{ZnCl}_{2}$ for $24 \mathrm{~h}$ and then UVB irradiated was measured and analysed by TLDA relative to untreated cells.

$\mathrm{ns}$, not significant $\mathrm{p}<0.05$

${ }^{1}$ with 2-tailed Student's t test

${ }^{2}$ at least \pm 2 -fold differences in each experiment between treated and untreated cells 


\section{References}

1. T. Kawamura, Y. Ogawa, Y. Nakamura, S. Nakamizo, Y. Ohta, H. Nakano, K. Kabashima, I. Katayama, S. Koizumi, T. Kodama, A. Nakao and S. Shimada, J Clin Invest, 2012, 122, 722-732.

2. B. Portnoy and M. Molokhia, Lancet, 1974, 2, 663-664.

3. J. R. Schwartz, R. G. Marsh and Z. D. Draelos, Dermatol Surg, 2005, 31, 837-847; discussion 847.

4. M. Gupta, V. K. Mahajan, K. S. Mehta and P. S. Chauhan, Dermatol Res Pract, 2014, 2014, 709152.

5. $\quad$ M. M. Molokhia and B. Portnoy, Br J Dermatol, 1970, 82, 254-255.

6. $\quad$ B. L. Vallee and K. H. Falchuk, Physiol Rev, 1993, 73, 79-118.

7. $\quad$ L. A. Lichten and R. J. Cousins, Annu Rev Nutr, 2009, 29, 153-176.

8. W. Maret, J Nutr, 2000, 130, 1455S-1458S.

9. A. Zamirska, L. Matusiak, P. Dziegiel, G. Szybejko-Machaj and J. C. Szepietowski, Pathol Oncol Res, 2012, 18, 849-855.

10. E. Emri, K. Egervari, T. Varvolgyi, D. Rozsa, E. Miko, B. Dezso, I. Veres, G. Mehes, G. Emri and E. Remenyik, J Eur Acad Dermatol Venereol, 2013, 27, e320-327.

11. T. G. Polefka, R. J. Bianchini and S. Shapiro, Int J Cosmet Sci, 2012, 34, 416-423.

12. B. W. Graf, E. J. Chaney, M. Marjanovic, M. De Lisio, M. C. Valero, M. D. Boppart and S. A. Boppart, Biomed Opt Express, 2013, 4, 1817-1828.

13. C. C. Wang, S. Wang, Q. Xia, W. He, J. J. Yin, P. P. Fu and J. H. Li, J Nanosci Nanotechnol, 2013, 13, 3880-3888.

14. S. D. Lamore, C. M. Cabello and G. T. Wondrak, Cell Stress Chaperones, 2010, 15, 309-322.

15. C. J. Stork, L. M. Martorano and Y. V. Li, Int J Mol Med, 2010, 26, 463-469.

16. L. Wang, W. Liu, S. H. Parker and S. Wu, Life Sci, 2010, 86, 448-454.

17. W. H. Wang, L. F. Li, B. X. Zhang and X. Y. Lu, Clin Exp Dermatol, 2004, 29, 57-61.

18. E. Jourdan, N. Emonet-Piccardi, C. Didier, J. C. Beani, A. Favier and M. J. Richard, Arch Biochem Biophys, 2002, 405, 170-177.

19. E. Jourdan, R. Marie Jeanne, S. Regine and G. Pascale, J Cell Biochem, 2004, 92, 631640.

20. M. O. Parat, M. J. Richard, S. Pollet, C. Hadjur, A. Favier and J. C. Beani, J Photochem Photobiol B, 1997, 37, 101-106.

21. T. D. Schmittgen and B. A. Zakrajsek, J Biochem Biophys Methods, 2000, 46, 69-81.

22. J. Winer, C. K. Jung, I. Shackel and P. M. Williams, Anal Biochem, 1999, 270, 41-49.

23. M. Szanto, I. Rutkai, C. Hegedus, A. Czikora, M. Rozsahegyi, B. Kiss, L. Virag, P. Gergely, A. Toth and P. Bai, Cardiovasc Res, 2011, 92, 430-438.

24. P. I. Oteiza, Free Radic Biol Med, 2012, 53, 1748-1759.

25. K. M. Taylor, P. Kille and C. Hogstrand, Cell Cycle, 2012, 11, 1863-1864.

26. K. M. Taylor, P. Vichova, N. Jordan, S. Hiscox, R. Hendley and R. I. Nicholson, Endocrinology, 2008, 149, 4912-4920.

27. R. A. Bozym, F. Chimienti, L. J. Giblin, G. W. Gross, I. Korichneva, Y. Li, S. Libert, W. Maret, M. Parviz, C. J. Frederickson and R. B. Thompson, Exp Biol Med (Maywood), 2010, 235, 741-750.

28. M. O. Parat, M. J. Richard, C. Meplan, A. Favier and J. C. Beani, Biol Trace Elem Res, 1999, 70, 51-68.

29. D. Lim, T. T. Phan, G. W. Yip and B. H. Bay, Int J Mol Med, 2006, 17, 385-389. 
30. E. Bellomo, A. Massarotti, C. Hogstrand and W. Maret, Metallomics, 2014, 6, 12291239.

31. B. L. O'Dell and J. D. Browning, Adv Nutr, 2013, 4, 287-293.

32. Y. Wang, U. Wimmer, P. Lichtlen, D. Inderbitzin, B. Stieger, P. J. Meier, L. Hunziker, T. Stallmach, R. Forrer, T. Rulicke, O. Georgiev and W. Schaffner, FASEB J, 2004, 18, 1071-1079.

33. P. Lichtlen, Y. Wang, T. Belser, O. Georgiev, U. Certa, R. Sack and W. Schaffner, Nucleic Acids Res, 2001, 29, 1514-1523.

34. C. Ma, L. F. Li and X. Chen, Br J Dermatol, 2011, 164, 479-482.

35. A. M. Bhujade, S. Talmale, N. Kumar, G. Gupta, P. Reddanna, S. K. Das and M. B. Patil, J Ethnopharmacol, 2012, 141, 989-996.

36. Y. C. Hseu, C. W. Chou, K. J. Senthil Kumar, K. T. Fu, H. M. Wang, L. S. Hsu, Y. H. Kuo, C. R. Wu, S. C. Chen and H. L. Yang, Food Chem Toxicol, 2012, 50, 12451255.

37. S. J. Chapple, R. C. Siow and G. E. Mann, Int J Biochem Cell Biol, 2012, 44, 13151320.

38. A. Blazquez-Castro, T. Breitenbach and P. R. Ogilby, Photochem Photobiol Sci, 2014, $13,1235-1240$.

39. A. O. Brightman, J. Wang, R. K. Miu, I. L. Sun, R. Barr, F. L. Crane and D. J. Morre, Biochim Biophys Acta, 1992, 1105, 109-117.

40. A. W. Linnane, M. Kios and L. Vitetta, Biogerontology, 2007, 8, 445-467.

41. E. Werner, J Cell Sci, 2004, 117, 143-153.

42. G. Y. Zhang, L. C. Wu, T. Dai, S. Y. Chen, A. Y. Wang, K. Lin, D. M. Lin, J. Q. Yang, B. Cheng, L. Zhang, W. Y. Gao and Z. J. Li, Exp Dermatol, 2014, 23, 639-644.

43. G. S. Lien, M. S. Wu, M. Y. Bien, C. H. Chen, C. H. Lin and B. C. Chen, PLoS One, 2014, 9, e104891.

44. M. Valko, D. Leibfritz, J. Moncol, M. T. Cronin, M. Mazur and J. Telser, Int J Biochem Cell Biol, 2007, 39, 44-84.

45. Y. J. Surh, J. K. Kundu, H. K. Na and J. S. Lee, J Nutr, 2005, 135, 2993S-3001S.

46. F. P. Noonan, J. A. Recio, H. Takayama, P. Duray, M. R. Anver, W. L. Rush, E. C. De Fabo and G. Merlino, Nature, 2001, 413, 271-272.

47. L. Marrot and J. R. Meunier, J Am Acad Dermatol, 2008, 58, S139-148.

48. T. Saito, T. Tezuka, R. Konno and N. Fujii, Jpn J Ophthalmol, 2010, 54, 486-493.

49. D. E. Godar and A. D. Lucas, Photochem Photobiol, 1995, 62, 108-113.

50. M. C. McCord and E. Aizenman, Front Aging Neurosci, 2014, 6, 77.

51. M. Cirone, A. Garufi, L. Di Renzo, M. Granato, A. Faggioni and G. D'Orazi, Oncoimmunology, 2013, 2, e26198.

52. M. Granato, V. Lacconi, M. Peddis, L. V. Lotti, L. Di Renzo, R. Gonnella, R. Santarelli, P. Trivedi, L. Frati, G. D'Orazi, A. Faggioni and M. Cirone, Cell Death Dis, 2013, 4, e730. 